\title{
Exploration and Practice of foreign student education
}

\author{
Songzhu Xia \\ College of Computer Science and Technology \\ Harbin Engineering University \\ Harbin, China
}

\author{
Chuheng Tang, Qiaosi Ge \\ School of Automation \\ lHarbin Institute of Technology \\ Harbin, China
}

\begin{abstract}
Higher education globalization has become a common trends, the foreign student education in China is also rapid development. Cultivation of high-level foreign students graduate quantity and quality, and has become a measure of the important symbol of the levels of running a university. Exploring study graduate training mode and management methods, it has the important theory significance and the practical application. The teaching management is the focus of the foreign graduate student education, this article from the course system, teaching staff, supervision mechanism and training graduate study in scientific research ability and creative spirit of four aspects, this paper introduces the study of graduate student training in exploration and practice experience and achievements.
\end{abstract}

Keywords- Recruit students, Teaching management, Logistics management

\section{INTRODUCTION}

The world is moving further toward economic globalization, higher education globalization has also become a common trend. With China's comprehensive national strength and international status improved, foreign student education is developing rapidly in China. Under the guidance of the principles of "expand the scale and improve the level, ensure quality, and standardized management”, the quantity and the quality of foreign students studying in China have a great upgrade, foreign student education has made gratifying achievements. In the economy, foreign student education can play an important role to ease the financial constraints of Chinese Universities, increasing employment opportunities, and promote the development of China's national economy. In politics, student education is conducive to develop an international friendly people, and help to promote the contacts and relations of China and the world. The quantity and quality of high level foreign students is an important symbol of a university level. In practice to train foreign students graduate, we explore and summarize a viable option, making the overall cultured of the Graduates' quality has improved significantly.

\section{ANALYSIS OF THE RESEARCH}

Each country has its own advantages and characteristics in management of foreign student education. Foreign student education began early in the developed countries, its cultivation mode after a long period of development has been more mature, and it's Cultivation Mode in many places worthy of our country to learn from. In Europe and America, and Asian countries like Japan, Singapore, its management of foreign student education has a high degree of standardization, and there is a clear division of labor in society. The school is only responsible for admissions, enrollment management and consulting, other is full of social management, so the school can concentrate on teaching work. Because government funding and policy support is relatively large, Students can easily apply to all kinds of scholarship, and this became one of the key factors in attracting foreign students. These countries take the policy easing in enrollment and teaching management, Entrance requirements In addition to the requirements of foreign language proficiency test must pass students without another exams. The mentor has a major decision. School implements the high drop-out rates, students must pass all courses, and complete all required for graduate level credits. Graduate Students also divided into courses Master and thesis Master, the thesis Master need through the thesis defense. Foreign graduate student in such aspects as tuition and scholarship issue enjoy national treatment, this play a role to encourage for the learning attitude and learning enthusiasm of students.

With the development of the economic system in our country, the foreign student education training mode also experienced closed, semi-closed, open three stages. After 1992,the Educational administration unveiled a new policy, gradually opening up the right of approval of the enrollment of foreign students, it also made new regulations on foreign students in medical charges, accommodation, etc., these policies make the college for the education of foreign students in training mode gradually become more flexible and diversified. Our college education of foreign students training mode but there are still certain problems and constraints, there is a big gap compared with developed countries.

\section{BROADEN THE RECRUITMENT CHANNELS}

Foreign graduate student education is the need of university internationalization, it also can improve the school's international reputation, enhance the discipline construction and scientific level. Foreign student education student education can enhance cultural exchanges, activate the school development potential, and enhance the level of education level. We should vigorously develop foreign student education, students enrollment is the beginning and the foundation of the International Education. Harbin Engineering University is located in the beautiful city of Harbin. Due to historical reasons, we and Russia and other 
countries with relatively dense, so it has advantage in recruiting these national students. We should grasp the advantage, to increase the number of students from Russia, Japan and other countries to recruit. While stabilizing the students from the third world countries in Asia, gradually attracting students from Europe and America.

Currently, there is a recruitment channels for a single and propaganda is not enough, etc. In addition to the scholarship students dispatched by the China Scholarship Council and Hanban, school should make full use of existing resources and teaching conditions, with the Western developed countries in many aspects, multi-level and multi-field cooperation to increase inter-school exchange. At the same time, school also send admissions institutions in some foreign cities hold to preach, to introduce foreign students to the school policy of foreign students. And school should expand the use of modern means such as media and network to recruit student propaganda, to show in school life and study aspects of students, foreign students can directly get admissions information.

\section{STRENGTHEN COURSES SYSTEM AND TEACHING STAFF CONSTRUCTION}

Cultivate foreign graduate student, the school must have a set of scientific, practical, complete curriculum system, which is directly related to the study of the quality of graduate students. Planning to foreign graduate student from the whole, and then detailed to arrange foreign graduate student courses, to construct a suitable post-graduate course system. Foreign graduate students come to a non-native environment of learning, they have mastered the basic language for daily communication, but they are still very difficult to understand the vocabulary, which become an obstacle to their learning. We carried out a number of auxiliary projects to help foreign graduate students learn vocabulary, including the creation of computer professional Chinese, Chinese graduate students help students graduate learn vocabulary. In order to let the foreign graduate students more quickly into the learning state, we use the classic English teaching, which is more convenient for them to read. Adopts full English teaching is also an important means of.

The professional knowledge structure of foreign graduate student is not comprehensive enough, foundation is weak, especially the basic knowledge of mathematics. We take note of the foreign graduate students' foundation and practical ability is weak, In the curriculum, we stratified opened basic course and experiment, gradually enrich their knowledge, make their beginning ability improved, provided a basis for their future scientific research and project. We organize teachers to write the Chinese language teaching materials suitable for foreign graduate students.

Having both ability and political integrity of the teachers team, is the key to guarantee the quality of foreign graduate study in the teaching. Foreign graduate supervisor should have open awareness and international awareness to grasp and understand the international forefront of scientific knowledge and research methods, with a broad range of cultural knowledge. At the same time, we should pay attention to the youth teachers' English teaching ability and strengthen the classroom teaching and presentation skills. On the one hand, we strict selection of international graduate teachers, on the other hand, we also have to optimize the foreign graduate student teachers. We put the teacher's selection, training, assessment, appointment of the organic combination, to implement the pre-job training, regular assessment, the survival of the fittest system, to keep the vigor and vitality of the foreign graduate student teachers. Through training in the teacher management process, the sense of responsibility of teachers is strengthened, and the teaching level and teaching methods are improved to ensure the quality of teaching.

\section{ESTABLISHMENT OF MONITORING MECHANISMS}

Build study in postgraduate teaching quality monitoring mechanism, to oversee normal study in graduate students teaching, its essence is to improve the teaching quality of the foreign graduate students. The purpose of the quality control mechanism is through careful analysis and evaluation of the process and the level of teaching, and accurately identifies the factors that affect the quality of teaching, and the proposed improvement program to improve the quality of education and teaching. Establishing the teaching quality monitoring mechanism to deepen the teaching management system to improve the quality of teaching and optimize the teaching process and the level of talent training.

The vice president in charge of teaching to be responsible for the students graduate work, by the director of general office specifically responsible for the implementation of the measures and daily student management. We specialize in computer teaching for many years, the appointment of a rich teaching and educating people experienced teachers as supervision, they have a deep understanding and profound knowledge of computer professional, familiar with the teaching and study of computer college graduate training mode. They oversee and guide the whole process of the study in graduate education from the selected classroom teachers, curriculum, textbook selection, coordination and communication between teachers and students, teaching effectiveness. They submitted a report to the dean of teaching quality, in order to ensure a steady improvement of teaching quality. We also established the evaluation system for graduate study in the final. They conduct a comprehensive assessment from the training process and the instructor's teaching method and the attitude to teachers. We value their opinions, to adhere to the existing good teaching methods, and to improve the training process of imperfect aspects.

\section{IMPROVE THE RESEARCH CAPABILITIES AND INNOVATIVE SPIRIT}

Scientific research ability and innovation spirit is the focus of high-level study in graduate education. The instructors will be introduced to each foreign graduate student training programs, they inform the training standards and the establishment of the appraisal system of each training links. The mentor will guide the Graduate Students 
actively participate in scientific research activities, supporting them to participate in various conferences, and encourage them to high-level international journal papers. Foreign graduate students through selecting topic, the practice of literature analysis, program design and implementation, thesis writing, develop their research capacity in this process and lay the foundation for future research work done creative. Tutor should guide the students to observe ground thinking, to dare the traditional challenges, and brave enough to challenge the authority. Frontier disciplines and interdisciplinary cross are the two major areas of innovation, tutor will make foreign graduate students understand the development direction and existing problems in the latest progress of this subject, instructors will guide foreign graduate students to broaden the basic theory and knowledge, to improve the knowledge structure. Let students to understand the main direction of research and involved topic, arousing their attention and interest.

Computer subject with strong practicality, mentor organized graduate students into different topics or projects, and guide students to practice to discover the problems of urgent need to solve. One mentor and 2-3 foreign graduate students form a team to complete a research project or part of a project, the mentor head worked as team manager. Foreign graduates' solve the problem in a real environment, which can check their deficiencies, and to add new knowledge and innovation in the work to improve the research capability. In the teacher work together with foreign graduate students, which can improve the affection between teachers and students, and also make the teacher know more about each student's characteristic, the mentor is more targeted to guide the foreign graduate students.

\section{LOGISTICAL MANAGEMENT}

The school should pay attention to foreign students in logistics management of construction. First, the school establishes and perfects the auxiliary project for postgraduate study and life. Foreign graduate students obtain information from the network, the relatives and friends, as well as other foreign students. Because of the convenience of network, so the school's website should give more study abroad life guidance and advice, at the same time set up students communication platform, which makes students have adapted to study abroad life to help the new students. Secondly, the school should improve the students' apartment hardware level, and improve the logistics management and service personnel quality. The school should offer affordable student apartment of students while equipped entertainment facilities and dining facilities case. Thirdly, the school provides opportunities for work-study program students, and provides support in terms of social medical insurance. Finally, we carry out rich and colorful activities for foreign graduate students.

\section{SUMMARY}

Education for foreign graduate students in the continuous development, we will continue the reform of higher education management, we must strive to train high-level high-quality foreign graduate students.

\section{ACKNOWLEDGMENT}

This paper is supported by the free exploration plan academic exchanges Funds for the Central Universities (HEUCF100612).

\section{REFERENCES}

[1] Qiuhong Guan, "Research on the training mode of education for foreign students,” Northeast Petroleum University,2010.

[2] Lixia Li, "Adhere to the teaching as the center to train students," China Light Industry Education, 1999, vol. 14,pp.24-25.

[3] Mingliang Wen."Seeing is believing is the most effective way of foreign student enrollment propaganda," Times Literature, 2008 vol.10,pp.177-178.

[4] Wenli Wang,Wenli Xu,"Engineering Colleges students enrollment Strategies,” Science \& Technology Information, 2009, vol.10,pp.340.

[5] Mingming Yu,"Study on some problems of foreign student management," Chongqing University,2010.

[6] Wuyi Zhang,"Reflections of foreign students in educational theory, “Exploring Education Development, 1999, vol.3, pp.72-74. 